\title{
KNOWLEDGE MANAGEMENT AND VIRTUALIZATION OF WORK AT HIGHER UNIVERSITIES
}

\begin{abstract}
The publication concerns the specifics of work in a virtual system and knowledge management at selected Higher Universities in Poland. This way of performing duties is becoming more and more popular and even required by cooperators from the near and distant environment. Universities should demonstrate flexibility in this area by adapting their work system to current trends and standards. The aim of the article is to describe some aspects related to the virtual work of academic teachers and the need to apply knowledge management in the long-term functional organization. The adopted hypothesis assumes that there will be intensification of processes related to virtualization of work at universities. The qualitative method was used to collect empirical data in the form of casual interviews. Up to now, interviews with academics have been conducted with three selected Polish universities (Academy of Social Sciences, University of Lodz, School of Finance and Management), overall thirty-seven workers took part in the research. A secondary analysis method was also used, consisting of a review of literature on the subject of national and international scope. The results of the publication are pilot studies, which are a prelude to further research covering both teachers and people managing science and didactic facilities in major voivodship cities in Poland.
\end{abstract}

Keywords: virtualization, knowledge management, ICT, e-work, e-teachers

\section{Streszczenie}

\section{Zarządzanie wiedzą i wirtualizacja pracy na uczelniach wyższych}

Publikacja dotyczy specyfiki pracy w systemie wirtualnym i zarządzania wiedzą w wybranych wyższych uczelniach w Polsce. Ten sposób wykonywania obowiązków staje się coraz 
bardziej popularny, a nawet wymagany przez współpracowników z bliższego i dalszego środowiska. Uczelnie powinny wykazać elastyczność w tej dziedzinie, dostosowując swój system pracy do obecnych tendencji i standardów. Celem artykułu jest opisanie niektórych aspektów związanych $\mathrm{z}$ wirtualną pracą nauczycieli oraz potrzebą zastosowania zarządzania wiedzą w długoterminowej organizacji i funkcjonowaniu podmiotów akademickich. Przyjęta hipoteza zakłada, że nastąpi intensyfikacja procesów związanych z wirtualizacją pracy na uczelniach. Do zebrania danych empirycznych wykorzystano metodę jakościową w formie wywiadów swobodnych. Przeprowadzono wywiady z pracownikami akademickimi z trzech wyselekcjonowanych polskich placówek wyższych (Społecznej Akademii Nauk, Uniwersytetu Łódzkiego i Wyższej Szkoły Finansów i Zarządzania), w badaniu wzięło udział ogółem 37 pracowników. Zastosowano również metodę analizy wtórnej, polegającą na przeglądzie literatury przedmiotu o zasięgu krajowym i międzynarodowym. Rezultatem publikacji są badania pilotażowe, które stanowią wstęp do dalszych badań obejmujących zarówno nauczycieli, jak i osoby zarządzające obiektami naukowo-dydaktycznymi w głównych miastach wojewódzkich w Polsce.

Słowa kluczowe: wirtualizacja, zarządzanie wiedzą, ICT, e-praca, e-nauczyciel

\section{Introduction}

The significance and the power of knowledge generated by experts were additionally reinforced by ICT development, thanks to which the chance of reaching the best employees able to cooperate with no limitations, has become greater. They can swap knowledge and ideas or form creative networks, owing to which their own and organization's capacity might be hugely multiplied [Wong, Laschinger, 2013].

There are currently no entities that would not use the possibilities of work virtualization. Thanks to this knowledge or information can be transferred in a faster and more effective way. To strengthen this effect, organizations decide to work on the basis of appointed teams, where there is a synergy effect and a better competence supplement than during individual tasks. The managers are faced with the challenge of acquiring skills related to managing virtual teams, which are groups that include employees who perform their duties in a remote and spatially mobile manner. The above conditions also apply to employees of higher education institutions, who can perform a number of their professional activities using ICT tools. This group is additionally characterized by the use of individual and organizational knowledge. Therefore, the next duty of the managers is to become familiar with the principles of knowledge management and then skillfully apply them.

The aim of the article is to describe some aspects related to the virtual work of academic teachers and the need to apply knowledge management in the longterm functional organization. The adopted hypothesis assumes that there will be intensification of processes related to virtualization of work at universities. The qualitative method was used to collect empirical data in the form of casual interviews. Interviews characteristically have an unstructured list of questions. This gives a chance to collect the material for comparative analysis from respondents. Limitation of the tools chosen by the author are a lesser number of respondents 
interviewed. However, the quality and accuracy of the material won't be possible with using other tools.

At the beginning authors carried out in-depth critical analysis of national and international literature. Interviews were initiated and conducted on a group of thirty-seven academic teachers in three senior higher education institutions in Poland (Social Academy of Sciences, Lodz University, School of Finance and Management). The persons surveyed are an academic teacher who conduct classes in colleges with the help of online courses.

\section{The importance of knowledge management}

Henryk Król and Antoni Ludwiczyński signify that the process of knowledge management, which is strictly correlated with intellectual capital, is often referred to by the management of the contemporary organization [Król, Ludwiczyński, 2010: 446]. It consists of four basic factors, which interact with each other can play a significant role in the functioning, development and value of the enterprise. Its elements are capital: human, customer (relationship), organizational (structural), market.

Due to the complexity of knowledge management, there is no single valid definition of this phenomenon. Kazimierz Perechuda believes that this is a very broad concept which can cover many aspects, since knowledge means the thoughts attributed to different authors, i.e., intangible beings [Zimniewicz, 2014: 115]. There are many types of knowledge. The situation is shown in Table 1 . It is also possible to identify knowledge management with human resource management, due to the aspects of generation, flow of this resource between the employed and cooperating with the organization.

David Gladstone, however, presents an approach that recognizes that knowledge acquisition, sharing and the right application is a priority for almost every employee, from different departments, regardless of the business sector. By adopting the interdisciplinary perspective of the definition described above, one can broadly illustrate its key meaning. Such an approach is represented by Mariusz Hofman and Elżbieta Skrzypek, who believes that knowledge management integrates all processes in the areas of innovation, creativity, consumer information, best practice, learning, competence development, value development, goals and applied new techniques and information and information technology.

Data and information are the foundation of knowledge that can be considered as a response to questions or problems. Knowledge based on purpose, people implementing, project or context can be differently interpreted [Nowosielski, 2010: 33]. 
Selected types of knowledge

\begin{tabular}{|l|l|}
\hline Creator & Type of Knowledge \\
\hline Scheler (1926) & Instrumental, intellectual, spirituals \\
\hline $\begin{array}{l}\text { Anderson (1975), Squire (1987), Fayol (1994) } \\
\text { based on Ryle (1949) }\end{array}$ & Declarated, procedural, meta knowledge \\
\hline Polanyi (1966) & Overt, qui et \\
\hline Savage (1996) & $\begin{array}{l}\text { Know - how, know - what, know - who, know } \\
- \text { why, know - when, see - where }\end{array}$ \\
\hline $\begin{array}{l}\text { Nonaka, Toyama, Konno (2000) (types of } \\
\text { knowledge acts) }\end{array}$ & Experimental, conceptual, synthetic, routine \\
\hline Gamble, Blakwell (2001) & Personalized, described, embedded \\
\hline
\end{tabular}

Source: Gierszewska, 2011: 42-57.

Often in organizations, the knowledge learned by employees is misused, i.e. it encounters barriers that prevent it from developing, implementing or commercializing. You may also find that the individual knowledge of the individual employees is dispersed. This means stopping the synergy effect of enhancing the current and future competencies of the organization. Kazimierz Zimniewicz believes that. It is therefore essential that the operators are aware of the possession and development of knowledge bases and platforms within the organizational structures that enable them to systematically accumulate, store, divide or improve. In the definitions of management of this resource, it is often emphasized that the creation of personalized databases, which are appropriate for the organization, should be used properly [Zimniewicz, 2014: 109]. It can be understood that platforms and databases have to facilitate the implementation of business tasks of an organization, that is:

- organizational learning - the process by which an entity collects information and/or knowledge;

- knowledge production - a process that binds up a multitude of information, transposes it in practical knowledge and useful for solving business problems;

- knowledge distribution - a process that provides easy access and the opportunity to share common organizational knowledge [Godes, Ofek, Sarvary, 2009: 28].

Organizational culture that implements knowledge management should represent and propagate processes such as: acquiring, processing and disseminating information. This will allow you to build the skills and competencies of both individual employees and the entire company. Introduction of process knowledge management in an organization requires the installation and subsequent updating of IT infrastructure (e.g. data platforms, computer networks, software, IT tools). It is also necessary to implement organizational solutions conducive to the 
development of the above described IT backbone. Managers should be aware of the implementation of incentive systems that reward employee attitudes that promote and implement knowledge management aspects in practice. An important element is also the appropriate selection of employees, i.e. already in the recruitment and selection processes, the current and potential skills and abilities should be explored, for example, the absorption of new skills, the desire to share knowledge, creativity, etc. It is also important for economic operators to have implemented and respected internal rules for the implementation of the various stages of knowledge management (i.e. its placement, transposition, collection, completion, codification, etc.).

Organization acquires new knowledge through: inheritance, action, borrowing or moving. Inheritance consists in taking over and continuing the development of knowledge on the founding patterns of the subject. Inherited knowledge can influence how the organization fills the business reality or perceives new information flowing from the target and general environment. Learning by acting, or assimilating it in practice, can take many forms:

- by analyzing the tasks carried out so far,

- transition from adaptive learning to transformation through challenging key assumptions and values,

- increasing the potential of the organization by experimenting, creating a search for solutions that have not been used yet (by a particular team or other entity),

- collecting and drawing conclusions from the experience of the underprivileged (now working as well as former) on degraded and private land [Jashapara, 2014: 94].

Borrowing and transferring new knowledge can take place through competitive or functional benchmarking processes. Organizations are increasingly opting to cooperate with other players because of the benefits of such an agreement. Cooperation is not just between organizations from different sectors, but also between entities in the same industry. Co-operation agreements in a given area minimize the risk of failure to implement new ventures, as the costs are spread over more partners. Enterprises have more and more: solutions, staff, time to implement projects, machines, equipment, etc.

The area of interaction of entities may concern e.g.:

- creating and operating a common base,

- organizing and maintaining a common R \& D facility, investment contracting facilities, training and retreat centers,

- implementing the same sales and export demands,

- developing and representing the position towards the intentions of central, local government, social organizations, etc.

Success in cooperation with other organizations depends on meeting certain criteria, facilitating and enabling such cooperation. These are among others:

- the succession of phases of the technological process,

- participation in creating a complex product or service,

- use of a common raw material base, 
- homogeneity of destination of products (services),

- embedding the work of individuals in a similar geographical area,

- the ability to use common infrastructure,

- a community of interests related to development paths, etc.

\section{Virtualization of organization}

Virtualization of any entity's activity exerts the application of flexible and scattered forms of performance which level the time and geographical differences. An example of interweaving tools of virtualization is i.e.: telework (remote work) and virtual teams.

The notion of virtual organization (virtual enterprise) was introduced by William Davidow and Michael Malone (1992) and latterly popularized by John Byrne (1993) [Zbiegień-Maciąg, 2006: 65].

Trying to define this kind of organization it is worth starting from explaining the meaning of a term 'organization' (the Latin 'organizatio' coming from 'organizare' means 'to organise, to arrange systematically'). As Ricky Griffin states "organization is a group of people who cooperate with each other in a systematized and coordinated way in order to achieve a certain set of aims" [Griffin, 1996: 35].

However, analyzing the meaning of 'virtuality', more contemporary definitions should be given because its etymology (the Latin 'virtualis', which means 'effective'; 'vitus' and 'utis' - masculinity, perfection, bravery, strength, power, morality) is definitely out-of date referring to the common use of this word. So from the very beginning one can be noticed the apparent contradiction because the English word 'virtual' means 'factual, real' and 'seeming, eventual, prospective'. One can seem that such a contradiction is irreconcilable, but in fact, it shows the character of virtual organization (see Table 2). Such an entity really works, as it produces goods, employs staff, generates profits, furthermore, it takes conventional companies. However, such a business is not reliable enough as it does not have its residence, and the staff is geographically scattered - they are a team although they have never met before [Zbiegień-Maciąg, 2006: 65].

A virtual enterprise is a form of collaboration of legally independent companies or natural persons who pass the goods or services to the market basing on mutual economic relationship. However, under the law it is a single enterprise facing other business entities. A key role in controlling all activities belongs to information technology and computer-based techniques.

Virtual organization is also defined as an entity which builds up a network of teams, institutions and people in loosely affiliated and undefined structures, all of whom have the same goal, that is provide services or produce goods for customers [Grudzewski, Hejduk, 2002: 256]. 
Table 2

Possible explanations for 'virtual'

\begin{tabular}{|l|l|}
\hline Explanation for 'virtual' & Virtual organization \\
\hline Unreal, but looking Real & $\begin{array}{l}\text { Virtual organization is perceived as a company } \\
\text { existing and operating in real life, however it is } \\
\text { only a temporary combination of independent } \\
\text { partners }\end{array}$ \\
\hline Intangible, using ICT & $\begin{array}{l}\text { An organisation exists in real life; it is created } \\
\text { by e.g. virtual products being a collection of } \\
\text { adequately combined information; virtual of- } \\
\text { fice does not exist; employees work in different } \\
\text { places and contact each other only by ICT tools }\end{array}$ \\
\hline Possibly existing & $\begin{array}{l}\text { An organisation does not exist, but it could arise } \\
\text { in some specific circumstances; these potential } \\
\text { possibilities may turn into cooperation for com- } \\
\text { mon goals }\end{array}$ \\
\hline Existing, but changing & $\begin{array}{l}\text { Cooperation in virtual organization is tempo- } \\
\text { rary; its structure is constantly changing, it is } \\
\text { dynamic and progressive }\end{array}$ \\
\hline
\end{tabular}

Source: Gach, 2007: 61.

On the basis of analysis of many definitions referring to virtual organization, which are accessible in the subject literature, a collection of determinants of this kind of structure can be developed. The determinants include:

- focusing on key competences,

- using ICT to the largest possible extent,

- basing on trust as the basic element of coordination and control,

- independence and equality of partners,

- using opportunities,

- individualization (customization) of products and services,

- consumer-orientation,

- diffuse identity,

- ncreased speed of actions,

- adaptability, flexibility and responding to the changing needs and conditionings,

- acceptance of changes and uncertainty,

- expanding the range of operations, possibility to operate globally,

- sharing knowledge and placing an emphasis on knowledge management in organization,

- lack of hierarchy - heterarchy,

- lack of legal status,

- opportunism,

- sharing leadership and risk,

- perpetual transformations - changeable participation, 
- emphasis on innovativeness and improvement,

- geographic dispersion,

- modularity,

- effectiveness in resource usage [Niedźwiedzińska, 2003: 212].

Virtual organization may bring the following benefits:

- greater speed of actions and flexibility,

- common policy in the field of business activity,

- greater chance of using specialized knowledge and skills (higher technological potential),

- cost effectiveness, and therefore also price reduction,

- reduction of investment outlay,

- application of cutting-edge techniques and management methods/styles (e.g. Just in Time Delivery),

- transaction execution despite legal obstacles [Niedźwiedzińska, 2003: 213-214].

Unfortunately, such organizations also face some dangers:

- lower reliability of institution which cannot be placed/based in the so-called real world,

- excessive dependence on other partners exchange,

- lack of binding legal regulations for enterprises belonging to a virtual organization or the law regulating contacts with customers (warranties, complaints etc.),

- lack of equal customs and tax regulations,

- possible participation of incompetent or unreliable partners in a virtual organization;

- lack of role models,

- lack of access to highly-advanced information technologies [Niedźwiedzińska, 2003: 214].

It is worth highlighting that wide diversification and fluctuation of virtual organization's staff prevents shaping a unified and cohesive behaviour pattern, norms and values, that is elements which create corporate culture. In a virtual organization there are two cultures - an internal one which connects people with their own community, and the one which imposes supporting the above-mentioned diversification as a general rule of virtual organization. This kind of cultural dualism makes defining of a virtual organization's identity extremely difficult or impossible. The notion of 'diffuse identity' is commonly known. It means that virtual organizations are relatively separated from the environment, and contrary to traditional businesses it is pretty hard to define their borders. A virtual enterprise might be theoretically huge, and additionally it often gives an impression of being a bigger than it appears to be [Porębska-Miąc, 2000: 72].

In a virtual organization greater emphasis should be placed on competences and work results of particular employees than on their standing or post-related privileges. Mainly those employees who take important task-related decisions should be empowered. Wide access to information and fast vertical communication channels should be provided for top management to respond to the questions, 
appeals or conclusions. Complete abandonment of vertical limits could lead to organizational chaos - their specific diffusion helps to facilitate spreading ideas and concepts, which respectively enables competent people to take decisions quickly. Heterarchy means integration of virtual organization so as to facilitate breaking vertical limits. It is a concept of organizational structure which, according to Piotr Płoszajski, constitutes an alternative to an organizational form somewhere between hierarchy and chaos [Płoszajski, 2001: 36].

Strict and impenetrable organizational limits reduce flexibility of actions or even make prompt and effective respond to the rapidly-changing external conditionings impossible. Virtual organization has its own limits only to such an extent that allows for maintaining its identity. Bearing in mind the rest of meanings, virtual organization does not have any limits or they are changeable and penetrable, or its limit becomes the sum of network constituent elements. It is strictly connected with the necessity of reformulating the term 'member of an organization' and replacing it by a more relevant and justifiable term such as 'participant of an organization.' In a virtual enterprise physical limits (company's tangible property protection system) are subjected to 'diffusion'. According to K. Perechuda they turn into virtual limits, such as:

- awareness of company's customer,

- customers' perception of a company,

- extension of promotion and advertising,

- legal security,

- licences, patents, copyright,

- relationships with consulting agencies [Perechuda, 2007: 81].

In a digital era an old and excessively hierarchical business model based on commands and control becomes redundant. All enterprises have to operate faster and more flexibly. In such conditions conventional hierarchical structures are superseded by flat and network ones. It entails the change to the function of coordination abandoning bureaucracy and formality in favour of non-formal, social forms. Power and authority does not dwindle or disappear in a flat or network organization, but they base on self-management and self-organization. Then molecularization of organization takes place, that is individual employees or groups can quit corporate structures and be given a possibility to build up their own quality, thus becoming "creators of quality." Dividing big companies into virtual teams effectively collaborating with each other allows for flexible, intended and effective operations.

\section{Virtual teams}

Considering international organizations, virtual teams are not only a good way to find appropriate and skilled workers, but also complete tasks on a nearly 24-hour basis, regarding time zones. Such work process organization allows to control 
the market and respond to rapidly-emerging possible changes in the activity area a given company is interested in.

Cost-effectiveness resulting from the commute necessity is another virtue as well. As a consequence, it can be the so-called misleading cost-reduction for an employer limiting the staff's pay rises required. The next factor considered a great asset of virtual teams is lower staff fluctuation, which manifests oneself in sick or one-day leaves. In the case of urgent personal matters or an employee's bad feeling, they run errands and come back to work, they do not take the whole day off as wage-earners in traditional companies do.

Work virtualization does not force employers to dismiss staff when they relocate the company. The team, which are not dependent on the place of business, continue their particular assignments.

A great benefit flowing from virtual teams is their increased effectiveness. In traditional solutions the labourers taking the common space, in most cases, spend time on other, non-work related tasks, e.g. social networks, gossiping, chatting about private plans. Taking virtual teams into account, the time wasted at the workplace is absolutely minimized due to the lack of or vastly limited opportunities for social interaction.

A key role of virtual teams is attributed to effective knowledge sharing aimed at better team performance, which respectively supports an organization's innovativeness. A good thing here is staff diversification succouring the whole virtual team's creativity. The expenses lowering innovativeness can be also minimized. These costs include e.g. financial problems or lack of appropriate human and technical resources in the domestic market.

An additional asset of virtual teams is their greater flexibility and sensitivity which allows an organization to quickly transform its activity and easily adapt to new challenges. Flexibility is caused by an increased number of employees with no changes to the organisation, flexible working time and workplace, maximizing employee potential through easier task allocation and responsibilities or workload distribution. The employees might join lots of teams owing to flexible working time [Stefaniuk, 2014: 28-36].

Virtual teams have drawbacks as well. One of them is a matter of technology. It often affects the decision if this kind of organisation should come into existence. On the one hand one has to consider all expenditure related to employee equipment and Internet connection, and security of all data transmitted between particular team members and the company's headquarters on the other. It is highlighted that danger connected with information leak is much greater in such organizational forms than in traditional ones. The possibility of controlling data stored in labourers' computers is minimized as it is unpredictable who else could have access to company's confidential information apart from authorised persons, that is workers, hence the risk of data loss. Besides, data transmission through network must be adequately secured. Everything depends on how important the information is and what data management-related costs must be incurred by a company. The question is if the above-mentioned expenses are comparable with staff employment-related ones which a conventional organization bears. 
It happens that funds invested into implementation of relevant technology or data security system are quite high at the outset and the effects resulting from its application can be noticeable after a certain time period. It may significantly prevent implementation of virtual teams.

It is worth mentioning that in many cases employee overstrain is considered an essential shortcoming. A labourer's overwork can be translated into their reduced efficiency and lowered performance. Virtual team members show greater "availability when waiting for new assignments" because they can do their work after the so-called working hours. Closing the company does not impact continuation of the work commissioned. However, in the long-run it does not contribute to more effective and better task completion.

\section{Virtualization of university teachers' work}

Online teachers see themselves as remote education instructors because they perform their occupational responsibilities with the help of ICT and conduct classes via an online learning platform working from home. They are aware and even suggest building remote employees' identity, as bearing in mind all mentioned definitions of work virtualization, academics are definitely good epitomes of eemployees. However, they are not treated like e-employees by institutions for which they provide their services. In most cases these organizations do not use the notion such as 'work virtualization' or generally speaking 'virtualization'. Their employers use the definition 'e-teacher' or 'e-trainer', but their awareness concerning the specificity of work and education process organization are not sufficient. Plenty of higher education institutions treat virtualization like a bonus for academics who, in the digitalization age, can work from home, outside their parent university, regardless of their place of residence. All institutions introduce a virtualization-based education offer to boost their attractiveness through the implementation of alternative education forms for the young highly-digitalized generation. They can also raise their competitiveness as they access a larger number of potential candidates living in a geographically dispersed environment. Furthermore, virtualization may foster finding competent and skilled academic staff members eagerly performing their responsibilities in many high-tech companies. Thus, such institutions may vastly increase the number of lecturers, professors, and teachers, who apart from subject-related knowledge are able to tackle a practical aspect of their work as well. Bearing this in mind, one can reconcile a modern approach in an education process placing an emphasis on combining of interests of the two closely related worlds, that is science and business. Lots of surveyed teachers admitted that they did not have enough time to conduct fulltime classes at the university headquarters. Virtualization gives them a greater opportunity to adjust time and class organization to students, thus responding to the needs of those who are more occupationally committed. It is not a matter of 
education process effectiveness assessment, but a matter of education process reorganization, which is supported online.

It is worth highlighting that some kind of dualism referring to education centres' perception of teachers' work and their identity can be noticed. On the one hand - modernity of universities and implementation of ICT into the process of work organization, which strengthens virtualization. On the other - certain traditionalism visible through the prism of conventional perception of academics. They are not called virtual staff, they were rather allowed to follow and apply a more modern and advanced education form. An online teacher is a traditional instructor, who apart from subject-related competences, possess IT skills enabling them work on an e-platform. Nevertheless, they are not perceived as virtual staff members. "I do not know exactly if the institution I am employed in knows what remote work lies in. A teleworker is a kind of absurd not existing in our structure" (woman: online teacher). Another respondent upholds: "I think I am a teleworker, but for and at the university I am just an ordinary teacher who was given a chance to use an online education platform ...I am still an ordinary teacher who can show their e-learning skills and the paradox is that I am not an e-employee" (man: online teacher). "Some time ago I delivered a baby and I live far away from university. I do not want to quit a job, therefore I started conducting e-classes. I have been working like this for some time and I do not know if I perceive myself as an e-employee, let alone my academy" (woman: online teacher).

A similar situation refers to scientific workers. They are rarely seen as remote workers. They write articles or thesis and despite the fact they send their work to institutes or editorial offices via email, they are not considered remote employees. One of the respondents interestingly comments on their approach: "I suppose I am a teleworker, but it is not my vision. I write scientific articles or papers and send them via email. I entered into computer-based cooperation with many periodicals. I guess it is called telework" (man: scientific labourer). Another interviewee concludes: "I receive scientific work and articles via email, correct and review them, and next send them back. For me this type of work is definitely remote, but perhaps only for me. Please ask anyone if they think the same as me" (man: research and education labourer). The respective interviewee says:

I have been preparing interim or final reports for the purposes of projects I participate in. I write them at home. I search for relevant information using Internet resources or basing on data received from my fellow workers. I am aware that I am a teleworker but not many people think and treat my responsibilities the same. (woman: scientific labourer)

Research labourers carrying out research studies in inter-institutional and international teams experience a similar approach. They are often called "project workers" not regarding how much time they spend outside the main project management centre and what profits a given education institution has due to minimizing off-site business assignment-related labour costs. 
I am working upon a big international project in which my university takes part. The time I am spending in front of the computer screen, my availability related to answering emails, forwarding materials, intermediating with documentation flow between parties is significant. I do not count working hours, letting alone overtime, in fact this term does not exist in a university environment. (woman: research and education labourer)

No one working at university perceives me as a virtual employee, the Head of Faculty points out that thanks to advanced technologies I can participate in studies conducted by international teams, I have access to database which is unavailable for others. Yes, I have to admit that these are really good sides, I am not complaining. However, talking about virtualization, I think that I am a good example of this kind of employee, and I also think so considering all publications dedicated to this issue. (man: scientific labourer)

Another important aspect mentioned by the surveyed is all equipment they need to perform their responsibilities such as: computer, Internet connection etc. In most cases academics are forced to use their own equipment, that is computers and wi-fi connection.

No one asks me if I need some equipment to do my work, e.g. notebook. The project is approved and it should be implemented. Sometimes the employer provides us with necessary equipment, sometimes not, but the work must be done. Personally I did not think about that. I have my own PC with all data stored, so I use it. (woman: research and education labourer)

....amortization, electricity or Internet bills - I know the labour code determines such things - but in fact, I have never wondered who should pay for this. (woman: research and education labourer)

...It did not make me reflect on it - I can be at university and work there - I have all equipment and stuff needed, but sometimes I would like to work from home, especially when I have some urgent things to do. In such a case it is a waste of time to commute to work. I do not want to claim for the money for equipment, electricity and Internet connection. I am not even thinking about that. Neither is my university. For both parties it is a kind of unwritten agreement. I gain recognition, experience and have an opportunity to work in an interesting virtual team. The university receives recognition, the research results and builds a wide cooperation network. I guess that is the point. The synergy effect is achieved. (man: scientific labourer)

People who deal with economic and statistical analyses in the form of telework while conducting research studies face a congruent dilemma.

Basically, whatever they did was performed at home, with the lesser or greater use of ICT tools, e.g. appropriate software (SPSS). Most of them work at university or provide their services for private companies handling this kind of activity and 
additionally they carry out economic or statistical analyses at home. One should be mentioned that software licences belong to the institutions (purchasing costs are quite high and individual persons can rarely afford it). The activity they pursue is typical of telework although they are not treated like e-employees by the entities they are hired by. "At university many people and teams implement projects but not everyone knows how to tackle that. Therefore, I help them (obviously for a fee) analyzing the statistics. It suits me, I am at home and can work in silence" (woman: statistical analyst). "I deal with economic analyses. I can work both at work and at home. I does not matter to the management. So if possible I telework from home. I perform my tasks much faster and more effectively, so I can do more work, which apparently results in a higher salary. I guess this is the strongest motivation" (man: economic analyst).

\section{Summary}

The results obtained from the conducted studies clearly indicate the need to use ICT tools while fulfilling the duties of academic teachers. This diversity covers activities related to the collection of research materials, familiarizing with literature, remote learning, communication with other team members or sending necessary data and information. Broad spectrum of activity indicates that knowledge and use of virtualization is a prerequisite for this professional group. Therefore managers can not perceive virtualization as an unnecessary cost but as a series of innovative solutions that facilitate better functioning and development of employees as well as the entire organization. The same analogy is indicated in the approach to knowledge management. This resource should be treated as non-financial capital that, if properly managed and developed, will contribute to achieving the desired competitive position. Knowledge management is a process that consists, among others, of locating, transferring, coding, sharing etc. In addition, remember to establish individual channels of its acquisition appropriate for a given employee or team. The managers who care for the organization to be classified and have the image of an innovation entity should be aware of the benefits resulting from the correct use of knowledge as a resource. The implementation of knowledge management principles entails the need to change the thinking about managing the organization. Apply a holistic approach in the perception of the subject, because excessive concentration on selected fragments only, may cause discrepancies in its functioning.

Building the awareness of work virtualization and knowledge management requires the management style reorganization, work organization, andequipping employees with the necessary tools. The research results show that the reluctance to implement virtualization system (as a conscious and responsible work process) derives from imprecise provisions on health and safety issues at work. The unwillingness to enter virtual work systems may be the result of imprecise regulations covering health and safety at work. Accidents at work, overtime, equipment 
or electricity-related settlements should be clearly identified. It is necessary to clarify the proceedings in the event of accidents at work, the settlement of overtime, the purchase and modernization of equipment or the settlement of electricity consumption. The results of the publication are pilot studies, which are a prelude to further research covering both teachers and people managing science and didactic facilities in major voivodship cities in Poland.

\section{References}

Applehans W., Globe A., Laugero G. (1999), Managing Knowledge: A Practical Web-Based Approach, Addison-Wesley, Reading (MA).

Gach D. (2007), Organizacja wirtualna [in:] B. Mikuła, A. Pietruszka-Ortyl, A. Potocki, Podstawy zarzadzania przedsiębiorstwami w gospodarce opartej na wiedzy, Centrum Doradztwa i Informacji Difin, Warsaw.

Gierszewska G. (2011), Zarządzanie wiedza w przedsiębiorstwie, Oficyna Wydawnicza Politechniki Warszawskiej, Warsaw.

Godes D., Ofek E., Sarvary M. (2009), Content vs. Advertising: The Impact of Competition on Media Firm Strategy, Marketing Science, 28(1) (January-February), 20-35.

Gressgård L.J. (2011), Virtual Team Collaboration and Innovation in Organizations, Team Performance Management: An International Journal, 17(1-2), 102-119.

Griffin R. (1996), Podstawy zarządzania organizacjami, transl. A. Jankowiak, Wydawnictwo Naukowe PWN, Warsaw.

Grudzewski W.A., Hejduk I.K. (2002), Przedsiębiorstwo przyszłości - wizja strategiczna, Wydawnictwo Difin, Warsaw.

Grudzewski W., Hejduk I. (2002), Przedsiębiorstwo wirtualne, Wydawnictwo Difin, Warsaw.

Hajro A., Gibson C.B., Pudelko M. (2017), Knowledge Processes in Multicultural Teams: Linking Organizational Diversity Climates to Teams Effectiveness, Academy of Management Journal, 60(1), 345-372.

Hanson D., Ward C., Chin P. (2012), Leading Virtual Teams Across National and Cultural Boundaries, International Leadership Journal, 4(3), 1-17.

Jashapara A. (2014), Zarządzanie wiedza, transl. J. Sawicki, Polskie Wydawnictwo Ekonomiczne, Warsaw.

Król H., Ludwiczyński A. (2010), Zarządzanie zasobami ludzkimi. Tworzenie kapitału ludzkiego, Wydawnictwo Naukowe PWN, Warsaw.

Niedźwiedzińska H. (2003), Wirtualizacja jako aktualny trend rozwoju, Acta Universitatis Lodziensis. Folia Oeconomica, 167, 207-216.

Nowosielski S. (2010), Koncepcje zarządzania organizacją. Problem terminologiczne, Prace Naukowe Uniwersytetu Ekonomicznego we Wrocławiu. Nauki o Zarzadzaniu, 4(137): Zarzadzanie w Teorii, 13-23.

Partyka-Pojęta J. (2004), Zarządzanie w organach administracji publicznej, Wydawnictwo Marka, Chorzów.

Perechuda K. (2007), Metody zarządzania przedsiębiorstwem, Akademia Ekonomiczna, Wrocław. 
Płoszajski P. (2001), Organizacja przyszłości - wirtualny splot kontraktów [in:] W. Grodzewski, I. Hejduk (eds.), Przedsiębiorstwo przyszłości, Warsaw.

Porębska-Miąc T. (2000), Organizacja wirtualna - mocne i słabe strony [in:] R. Knosala (ed.), Komputerowo zintegrowane zarzadzanie, Wydawnictwa Naukowo-Techniczne, Warsaw.

Przytuła S. (2007), Pozyskiwanie menedżerów do przedsiębiorstw międzynarodowych, Oficyna Wydawnicza a Wolter Kluwer business, Kraków.

Rad P.F., Levin G. (2003), Achieving Project Management Success Using Virtual Teams, J. Ross Publishing, Plantation.

Stefaniuk T. (2014), Komunikacja w zespole wirtualnym, Wydawnictwo Difin, Warsaw.

Wong C.A., Laschinger H.K.S. (2013), Authentic Leadership, Performance, and Job Satisfaction: The Mediating Role of Empowerment, Journal of Advanced Nursing, 69(4), 947 959.

Zbiegień-Maciąg L. (2006), Nowe tendencje $i$ wyzwania w zarządzaniu personelem, Wolters Kluwer Poland, Kraków.

Zimniewicz K. (2014), Współczesne koncepcje i metody zarządzania, Polskie Wydawnictwo Ekonomiczne, Warsaw. 